\title{
Assessing the Contribution of Human Capital on Business Performance
}

\author{
Sarminah Samad, Member, IACSIT
}

\begin{abstract}
This paper presents a research finding on the relationship between human capital and business performance. The objectives of the study were to examine the relationship between human capital and business performance. Further, the study determined the contribution of human capital on business performance. Finally the study examined the most important aspect of human capital that influenced business performance. Data in this study was collected from a sample of 390 managerial staff in Malaysian logistics companies based on stratified random sampling. The obtained data were analyzed using SPSS Version 20. The study found that human capital aspects are related to business performance. The study revealed that all aspects of human capital contributed significantly to business performance. The findings indicated that human capital aspects of employees' competency and creativity emerged as the main factor that influenced business performance. This implies that competency and creativity have significantly enhanced the business performance in Malaysian logistics companies. Findings, implications and recommendations for future research from this study are discussed.
\end{abstract}

Index Terms-Human capital, business performance.

\section{INTRODUCTION}

Human capital has been theoretically and empirically linked to business performance. Since a couple decades ago a number of comparative studies on the human capital-performance link indicated that certain aspects of human capital are conducive to business performance [1] and [2]. Further the current business environment has change rapidly due to technology advancement, working environment and the emphasis on cost effectiveness [3]. The complexity of business organization environments demands employees who are proactive, positive and having adequate quality of human capital [2]. Most organizations have embraced human capital as one of the sources of competitive advantage to enhance better performance. In pursuit of sustainable organization, employees of Malaysian private sectors particularly in logistic companies are left with no other option but to gain competitive advantage by ameliorating its performance [4]. [5] Suggested that in an intense globalised competition human capital has been recognised as one of the crucial components that drive the economic growth and business performance.

Although a considerable number of studies in this area, there are limited empirical studies examining the relationship

Manuscript received June 20, 2013; revised August 23, 2013.

Sarminah Samad is with Arshad Ayub Graduate Busines School, Faculty of Business Management, MITRANS, IKAZ, IBE, University Teknologi MARA Malaysia (e-mail: sarminasamad@gmail.com). between human capital and its different aspects on important business performance in Malaysian logistics industries [6]. Further, most organizations do not understand the nature of human capital which according to [7] the multidisciplinary nature of human capital lends to richness of perspective and difficulty for valuation. Since much of the similar research has focused on the developed countries with certain business environment and different perspectives of human capital, [8] and [2] pointed out the need of study to be carried out in Asian region particularly in Malaysia. Although previous literature has identified human capital as the predictor of business performance, however aspects of human capital that are required for logistic companies in Malaysia have not been highlighted [9]. This paper highlighted the link of human capital (in terms of training and education, knowledge, skills, competence and creativity and attitude) on business performance. In addition the implementation of Malaysian Economic corridors and its logistics related business is also hindered by qualified human capital in terms of motivation, skills, knowledge, competency, training and development [2]-[4] and [9]. [4] and [9] have found that human capital of Malaysian logistics managerial staff are still less creative and incompetent. This study therefore examined the relationship of human capital and business performance in Malaysian logistic companies.

\section{LITERATURE REVIEW}

\section{A. Human Capital}

Issues concerning the definition and measure of human capital and its impact on organizational outcomes have been debated by scholars for a past few decades [9]. Different perspectives of human capital have been viewed by previous scholars [10]. According to [11] human capital pertains to individuals' knowledge and abilities that allow for changes in action and economic growth. Individuals' knowledge and abilities can be secured from various approaches. Formal training and education are among approaches or mechanism of human capital development.

Among the postulated models pertaining to human capital are firm specific human capital model, Industry specific human capital (industry-related know-how) and individual specific of human capital model. [12] suggests that firm specific human capital model which consists of skills and knowledge that are valuable for a specific firm may give advantage for organizational and business performance over its competitors. Another model is Industry-specific human capital suggested by [13] and [14]. This concept derived from 
experience specific to an industry or nature of business, the role of industry experience on the growth and economic performance of entrepreneurial ventures as well as society. The presence of industry-related know-how is considered important in creating innovations when new product or process ideas result from the combination of intimate communication among network partners and the use of technology. [15] suggested individual-specific human capital model which relates to knowledge that is applicable to a broad range of firms and industries; including general managerial and entrepreneurial experience, the level of academic education and training.

Reference [16] has suggested human capital concept with a combination of employees' competence, employees' attitude and employee's creativity. Human capital is also defined as the value of individual knowledge and talent in organization that includes know-how, capacities, competence, attitude, intellectual agility and creativity [12] and [8]. [17] classified human capital in a form of competencies such as skills, know-how and employee commitment such as loyalty to their work and company. Meanwhile [18] proposed human capital which constitutes education, business experience and level of motivation.

According to [19] human capital consists of four key attributes: 1) flexibility and adaptability; 2) enhancement of individual competencies; 3) the development of organizational competencies and 4) individual employability. [20] developed a model of competent manager that emphasized on competency as key to human behaviors. Further [20] has improved this competencies model as the underlying characteristics of an employee which result in effective and superior performance in a job. The characteristics include traits, motive, skill, person's self-image, body of knowledge and person's social role (cognitive and affective). [21] suggested that to face with challenging competition, managers need to have competencies in effective program design and teaching methods for learning. Further, in order to be effective mangers they need to have competencies in two areas mainly competencies as behavioral manifestations of talent (affective), and secondly, competencies in a holistic theory of personality (Cognitive). This implies that cognitive and affective aspects of learning experiences are important for managers in logistics companies.

Preceding discussions conclude that human capital can be addressed from various views such as individual (tangible and intangible), cognitive, affective and organization. The intangible aspects of human capital include motivation, personality attributes, attitude, commitment and behaviors. This paper highlights human capital from both perspective of cognitive (training and education, knowledge, skills, competency and creativity) and affective (employees' attitude). Cognitive and affective aspects of human capital are important resources for business and organizational performance. This notion relates to Resource Based View (RBV) theory that emphasizes the importance of resources to gain competitive advantage and improve business performance [9].

\section{B. Linking Human Capital and Business Performance}

Reference [22] postulates that theories play key roles in explaining how things work and the existence of phenomena which help researchers conduct the study and find out the outcomes of study and some practices. Although according to [23] no theory is exclusively right to explain the whole phenomenon of the study however researcher may select the most applicable theory that relevant to the study. This study is grounded from the RBV theory which suggests that available resources contribute to the competitive advantage and increase business performance. These resources are assumed to generate uniqueness that lead to competitive advantage and business performance [24]. RBV highlights the need of resources to have unique characteristics to allow organizations achieve their competitive advantage and performance. Among the unique and important characteristics as suggested by [24] and [9] are: 1) valuable, 2) Rare, 3) difficult to imitate 4) non substitutable and 5) imperfectly mobile.

[25] classified resources based on: 1)Assets - a) tangible (land, plant and machines, people etc.), b) intangible procedure and systems, knowledge, brands and reputations etc) and 2) Capabilities - a) individual or human capital (customer care, individual or group learning organization, leadership skills etc) b) group (customer orientation, group learning, interpersonal skills, etc and c) corporate (market orientation, organization learning, portfolio management, innovation, planning processes etc).

In order to gain competitive advantage and business performance according to [9] depend on the characteristics of human capital that have capacity to develop the capabilities internally and the cost of acquiring them in the market. RBV suggests that organizations are fundamentally idiosyncratic, and over time accumulate unique combinations of resources and skills which allow them to garner rents on the basis of "distinctive competence" [26]. [27] revealed that human capital is one of the important resources that contributes towards business performance. It has been highly emphasized that internal resources that include human capital are crucial to sustained effectiveness and business performance [28]. According to [29] human capital is an "invisible asset" that will contribute towards business excellence and performance.

Previous studies revealed the link between human capital and business performance. [30] relates the significant role of human capital on firm's competitiveness and performance. Further, continuous improvement of employees in terms of knowledge, skills and abilities is important for business input and performance [8]. Human capital has been found to be related to high quality of employee, productivity, longevity of companies, greater tendency to business and economic growth [31] and [32]. [33] found a significant relationship between human capital management and economic and business outcomes (performance and productivity).

Significant contribution of human capital in any industries including logistic companies has been emphasized widely in literature. Studies on motivational aspects, knowledge, skills and competencies required for logistician revealed their impact on business performance [34]. Logistician competencies are derived from the three main dimensions of 
business, logistics and management (BLM) framework [35]. This BLM framework has been used in previous study of competency among logistics managers [34]. According to [9] studies about the competency of Malaysian logisticians have not been widely pursued. Literature has also highlighted the need for human capital dimensions such as training and development, knowledge, skills, creativity, competency and employees' attitude to improve performance of logistics companies especially in the supply chain management (SCM) of suppliers [9].

\section{Business Performance}

Organizational performance has been commonly focused on two areas of research stream mainly on economic perspective and the organizational perspective. The economic perspective emphasizes the importance of external market factors such as the firms' competitive business position and anything related to financial aspects. The organizational or non economic perspective builds on behavioral and sociological paradigms and their fit with the environment which includes quality of services (such as employee satisfaction and customer satisfaction) quality of product and competitiveness [36].

Different authors have proposed different approaches to measure organizational and business performance [37]. [38] have identified ten different types of performance measurements and narrowed it down to three main dimensions: financial performance, business performance and organizational effectiveness. Previous research has used different measures of business and financial performance. These models include profitability, gross profit, return on asset (ROA), return on investment (ROI), return on equity (ROE), return on sale (ROS), revenue growth, market share, stock price, sales growth, export growth, liquidity and operational efficiency [9] and [39]. This study focused business performance in terms of productivity, profitability and market valuation as suggested by [9] and [40]. In sum previous studies and RBV theory provided support on the link between human capital and business performance.

\section{Hypotheses of the Study}

Based on the preceding literature and discussions the following hypotheses were proposed in this study:

1) H1: There is a positive and significant relationship between human capital and business performance,

2) H2: There is a significant contribution of human capital on business performance and

3) H3: Competency and creativity will be the most important human capital aspect that influenced business performance.

\section{RESEARCH METHODOLOGY}

Participants in the study were managerial staff in Malaysian logistics companies. 600 self administered questionnaires were distributed to the staff of the selected logistics companies based on the stratified random sampling. 390 useable questionnaires were used in the statistical analysis representing a response rate of $65 \%$. The dependent variable of the study was business performance. This variable was measured based on productivity, profitability and market evaluation. The questionnaire was developed by the author and adapted from [9], [40] and [41]. The scale consists of 18 items and respondents were asked to give their response based on a five-point Likert-type response with $1=$ strongly disagree to $5=$ strongly agree. The reliability coefficient for overall business performance components was .95 .

The independent variable in this study was human capital. This variable was measured based on the adapted instrument developed by [16], [42] and [43]. This instrument measures dimension of human capital mainly on training and education (5 items), knowledge (6), skills (6), employees' competence and creativity (6 items), and employees' attitude (5 items). The respondents were asked to give their response based on a five-point Likert-type response with $1=$ strongly disagree to 5 $=$ strongly agree. The reliability coefficient for all components of human capital is 92 .

\section{RESULtS}

\section{A. Demographic Profiles}

The results from the study revealed that more than half $(63 \%)$ of the respondents are male and $37 \%$ female. Whilst nearly $49 \%$ of the respondents are those within the range of more than 40 to 50 years and nearly $49 \%$ are from middle management staff. More than half (51\%) of the respondents have bachelor level of qualification.

\section{B. The Relationship between Human Capital and Business performance (HI)}

Table I presents the correlation analysis of the study variables to answer the first hypothesis of the study. As shown in Table 1, all aspects of human capital are correlated to each other and are positively related with business performance. Thus the hypothesis (H1) was accepted. This study concludes that human capital and its aspects have significantly enhanced the business performance. Examining the relationship of each variable, the analysis reveals that the strength of the relationship ranges from low to moderate, positive and significant relationship. Based on data in Table 1 there is no issue of collinearity in this data as the correlations between the independent variables are not high. This implies that a multiple regression analysis can be carried out to answer the hypotheses $\mathrm{H} 2$ of the study.

TABLE I: CORRELATION COEFFICIENTS OF THE MAIN VARIABLES

\begin{tabular}{|c|c|c|c|c|c|c|c|c|}
\hline Mean & SD & & 1 & 2 & 3 & 4 & 5 & 6 \\
\hline 3.33 & 0.70 & 1 & & & & & & \\
\hline 4.24 & 0.42 & 2 & $.55^{*}$ & & & & & \\
\hline 2.76 & 0.73 & 3 & $.53 *$ & $.46^{*}$ & & & & \\
\hline 3.16 & 0.72 & 4 & $.50 *$ & $.24 *$ & $.26^{*}$ & & & \\
\hline 2.53 & 0.82 & 5 & $.43 *$ & $.47 *$ & $.37 *$ & $.45^{*}$ & & \\
\hline 2.43 & 0.82 & 6 & $.53^{*}$ & $.48^{*}$ & $.39^{*}$ & $.20 *$ & $24 *$ & $\begin{array}{l}0 \\
0\end{array}$ \\
\hline
\end{tabular}

Note: $* p<.05,1$.Training and education 2.Knowledge 3. Skills, 4 Employees' competence and creativity 5. Employees' attitude 6. Business performance 


\section{The Contribution of Human Capital on Business} Performance (H2)

Table II presents the results of multiple regression analysis to answer the hypotheses $\mathrm{H} 2$ of the study. In order to answer the hypothesis $\mathrm{H} 2$ of the study all of the human capital aspects were regressed with business performance. As can be seen on Table II, the $\mathrm{R}^{2}$ value for human capital is .47 indicating 47 percent of variance in business performance was explained by human capital aspects. This result therefore provided support for hypothesis $\mathrm{H} 2$ of the study that there is a significant contribution of human capital on business performance. The findings of this study concluded that the overall human capital aspects contributed significantly on business performance.

TABLE II: THE CONTRIBUTION OF HUMAN CAPITAL ON BUSINESS PERFORMANCE

\begin{tabular}{|l|c|c|c|l|l|}
\hline \multirow{2}{*}{} & \multicolumn{5}{|c|}{ Business performance } \\
\cline { 2 - 6 } & \multicolumn{1}{|c|}{ Vtd $\beta$} & $t$ & $R^{2}$ & $f$ & $P$ \\
\hline Human capital: & & & 0.47 & 98.21 & $.000^{*}$ \\
\hline $\begin{array}{l}\text { Training and } \\
\text { education }\end{array}$ & .51 & 1.49 & & & $.000^{*}$ \\
\hline Knowledge & .35 & 1.96 & & & $.000^{*}$ \\
\hline Skills & .47 & 1.60 & & & $.000^{*}$ \\
\hline $\begin{array}{l}\text { Competency and } \\
\text { creativity }\end{array}$ & .56 & 3.36 & & & $.000^{*}$ \\
\hline Attitude & .52 & 3.36 & & & $.000^{*}$ \\
\hline
\end{tabular}

Note: $* p<.05$

\section{The Most Important Aspect of Human Capital for} Business Performance (H3)

The H3 of this study was to identify the most important aspect that influenced business performance. Examining each aspect of human capital as depicted in Table II, all aspects of human capital had a positive and significant contribution on business performance. The results showed that competency and creativity had the highest beta value of .56. The second highest is attitude followed by training and education, skills and knowledge. This indicated that competency and creativity aspect emerged as the most important factor for business performance. The result therefore supported the third hypothesis of the study that competency and creativity was the most important aspect of human capital in enhancing business performance. Therefore the hypothesis $\mathrm{H} 3$ was accepted.

\section{CONCLUSION}

The purpose of this study was to examine the relationship between human capital and business performance. Further, it determined the contribution of human capital on business performance. Finally the study attempted to identify the most important aspect of human capital that influenced business performance. The results based on the correlation matrix and regression analysis found that all of the human capital aspects were positively related to business performance and had a positive and significant impact on business performance. Meanwhile competency and creativity emerged as the most important aspect of human capital in enhancing business performance. This finding in tandem what has been highlighted by [4] and [9] on the need of logistics managers to be creative and competent. The results also implied that all of the human capital components served as the contributing factor and play important role in enhancing business performance in Malaysian logistics companies.

Findings of this research highlight the importance of human capital as the key component of internal resources in securing competitive advantage and achieving business performance in Malaysian logistics companies. It provides insight on the importance of companies' investment on human capital. Companies may need to have a planned program on human capital (especially related to training and education, skills, knowledge, competency and creativity and attitudes), in order to secure greater performance and gain competitive advantage for their long term survival in business. The correlation results indicates the existence of an interactive relationship between human capital aspects and business performance and that the companies should understand and improve its level with an overall point of view. This is important for the company to remain dominant in current business-economy based on knowledge and human capital as suggested by [2], [4] and [9]. The highest influence of competency and creativity on business performance implied managers need to be competent and creative to ensure organizational performance. Besides that it is important for the companies to motivate the employees to ensure they are always committed and motivated as this will overcome turnover intentions and their commitment and contribute to productivity and performance of the company [43]. This is in line with the findings of this study which indicated that attitudinal aspect has emerged as the second most important factor in enhancing business performance. This is among the required human capital aspects in Malaysian logistics companies [2]-[4] and [9]

Findings of this study are in tandem of previous studies [9], [28], [44] and [45]. The results of the study also are able to validate the applicability of RBV theory which explains the importance of resources (human capital) to create competitive advantage and increase business performance in logistics companies. Results from this study are applicable for practical and theoretical purposes. This study also serves as a starting point for further study in this area. For purposes of generalizability further study can be validated by using different samples and approaches in a variety of settings.

\section{ACKNOWLEDGEMENT}

This research was supported and funded by Ministry of Higher Education and Malaysian Institute of Transport.

\section{REFERENCES}

[1] A. Seleim, A. Ashour, and N. Bontis, "Human capital and organizational performance: a study of Egyptian software companies," Managing Decision, vol. 45, no. 4, pp. 789-901, 2007.

[2] S. Samad, "Examining the predictors of employee work outcomes-case study in logistics companies," Journal of Advances in Natural and Applied Sciences, vol. 6, no. 6, pp. 723-730, 2012.

[3] S. Samad, "Examining the organizational politics and job performance," Australian Journal of Basic and Applied Sciences, vol. 5, no. 12, pp. 1353-1363, 2011.

[4] S. Samad, "The influence of Leadership Styles on Organizational Performance of Logistic Companies," International Business Management, vol. 6, no. 3, 2012, pp. 374-383. 
[5] C. J. Huang and C. J. Liu, "Exploration for the relationship between innovation, IT and performance," Journal of Intellectual Capital, vol. 6, no. 2, pp. 237-252, 2005.

[6] M. Cabirta and N. Bontis, "Intellectual capital and business performance in the portuguese banking industry," International Journal of Technology Management, vol. 1594, pp. 235-237, 2008.

[7] N. Bontis and A. Serenko, "A follow-up ranking of academic journals," Journal of Knowledge Management, vol. 13, no. 1, 2009.

[8] S. Samad, "The role of creative organizational climate on learning organization- A key component of knowledge management," in Proc. Computer Engineering and Applications (ICCEA), 2010 Second International Conference on Knowledge Discovery, Bali, Indonesia, vol. 2, March, 2010, pp. 404-409.

[9] S. Samad, "The influence of innovation and transformational leadership on organizational performance," Procedia-Social and Behavioral Sciences, vol. 57, pp. 486-493, 2012.

[10] J. Florin, M. Lubatkin, and W. Schulze, "A social capital model of high-growth ventures," Academy of Management Journal, vol. 46, no. 3, pp. 374-384, 2003.

[11] J. S. Coleman, "Social capital in the creation of human capital," American Journal of Sociology, vol. 94, pp. 95-120, 1988.

[12] W. R. Sandberg, New venture performance: The Role of Strategy and Industry Structure, Lexington, MA: Lexington Books, 1986.

[13] R, Siegel, E. Siegel, and I. C. McMillan, "Characteristics distinguishing high growth ventures," Journal of Business Venturing, vol. 8, pp. 169-180, 1993.

[14] M. Kenney and U. Burg, "Technology entrepreneurship and path dependence: Industrial clustering in Silicon Valley and Route 128,' Industrial and Corporate Change, vol. 8, pp. 67-103, 1999.

[15] J. M. Pennings, K. Lee, and A. Witteloostuijn, "Human capital, social capital and firm dissolution," Academy of Management Journal, vol 41, pp.425-440, 1998.

[16] J. Chen, Z. Zhu, and H. Y. Xie, "Measuring intellectual capital: a new model and empirical study," Journal of Intellectual Capital, vol. 5, no. 1, pp. 195-211, 2004.

[17] H. S. Rodrigues, P. F. Dorrego, and C. F. Jardon, "The influence of human capital on the innovativeness of firms," The International Business and Economics Research Journal, vol. 9, no. 9, pp. 53-63, 2010.

[18] I. Pena, "Intellectual capitaland business start-up success," Journal of Intellectual Capital, vol. 3, no. 2, pp. 180-198, 2002.

[19] T. N. Garvan, M. Morley, P. Gunnigle, and E. Collins, "Human capital accumulation: The role of human resource development," Journal of European Industrial Training, vol. 25, no. 20, pp. 48-68, 2001.

[20] R. E. Boyatzis, The Competent Manager: A Model for Effective Performance, Mississauga, Ontario: John Wiley and Sons, 1982.

[21] R. E. Boyatzis, E. C. Stubbs, and S. N. Taylor, "Learning cognitive and emotional intelligence competencies through graduate management education," Academy of Management Learning and Education, vol. 1, no. 2, pp. 150-162, 2002.

[22] K. Culver. (October 2010). What is the function of theories in educational administration. [Online]. Available: http://ww.ehow.com/list

[23] K. C. Costley. (2012). Why do we have theories. Education Resources Information Centre. [Online]. Available: http://www.eric.ed.gov

[24] J. B. Barney, "Strategic factor markets: expectations, luck and business strategy," Management Science, vol. 32, no. 10, pp. 1231-41, 1986.

[25] G. J. Hooley, A. Broderick, and K. Moller, "Competitive positioning and the resource based view of the firm," Journal of Strategic Marketing; vol. 6, no. 2, pp. 97-115, 1998.

[26] J. B. Barney, "Firm resources and sustained competitive advantage," Journal of Management; vol. 17, no. 1, pp. 99-120, 1991.

[27] R. A. Swanson and E. F. Holton, Foundation of Human Resource Development, New York: Berrett Koehler, 2001.

[28] P. M. Wright, G. C. McMahan, and A. McWilliams, "Human resources and sustained competitive advantage: a resource-based perspective," International Journal of Human Resource Management; vol. 5, no. 2, pp. 301-26, 1994.

[29] H. Itami, Mobilizing Invisible Assets, Cambridge: Harvard University Press, 1987.

[30] T. Agarwala, "Innovative human resource practices and organizational commitment: An empirical investigation," International Journal of Human Resource Management, vol. 14, no. 2, pp. 175-197, 2003.
[31] S. J. Goetz and D. Hu, "Economic growth and human capital accumulation: Simultaneity and expended convergene tests," Economics Letter, vol. 51, pp. 355-362, 1966.

[32] S. Samad, "Assessing the differential effects of quality management system on product quality and business performance," Journal of International Review of Business Research Papers, vol. 3, no. 4, November 2008

[33] N. Bontis and J. Fitzenz, "Intellectual capital ROI: A current map to human capital antecedents and consequences," Journal of Intellectual Capital, vol. 3, no. 30, pp. 223-247, 2002.

[34] V. V. Thai, S. Cahoon, and H. T. Tran, "Skill requirements for logistics professionals: Findings and implications," Asia Pacific Journal of Marketing and Logistics, vol. 23, no. 4, pp. 553-574. 2011.

[35] P. R. Murphy and R. F. Poist, "Skill requirements of senior-level logisticians: A longitudinal assessment. Supply Chain Management," An International Journal, vol. 12, no. 6, pp.423-431, 2007.

[36] S. J. Tvorik and M. McGiven, "Determinants of organizational performance," Management Decision, vol. 35, no. 6, pp. 417-435, 1997.

[37] J. Ford and D. Schellenberg, "Conceptual issues of linkage in the assessment of organizational performance," The Academy of Management Review, vol. 1, pp. 49-58, 1982.

[38] D. I. Prajo, T. S. Laosirihongthong, and S. Boon-Itt, "Manufacturing strategies and innovation performance in newly industrialized countries," Industrial Management and Data Systems, vol. 107, no. 7 , pp. 52-68, 2007.

[39] N. Venkatraman and V. Ramanujam, "Measurement of business performance in strategy research: a comparison approaches," Academy of Management Review, vol. 11, pp. 801-818, 1986.

[40] A. Katou, "The impact of human resources development on organizational performance: Test of a causal model," Journal of Behavioral and Applied Management, vol. 5, pp. 335-356, 2009.

[41] F. A. P. Gimenez, "The benefits of a coherent strategy for innovation and corporate change: a study applying miles and snow's model in the context of small firms," Strategy and Innovation in SMEs, vol. 9, no. 4 pp. 235-244, 2000

[42] A. A. Sharabati, S. N. Jawad, and N. Bontis, "Intellectual capital and business performance in the pharmaceutical sector of Jordan," Management Decision, vol. 48, no. 1, pp.105-131, 2010.

[43] N. Bontis, "Intellectual capital: an explorotary study that develops measures and models," Management Decision, vol. 36, no. 20, pp. 63-76, 1998

[44] S. Samad, "Unravelling the different effects of quality and human resource management aspects on organizational performance," in Proc. Management and Engineering Conference ICIME, The 2nd IEEE International Conference on Information Management and Engineering, IEEE and ICIME, 2010, pp. 162-167.

[45] S. Samad, "Examining the influence of organizational politics on job performance," Australian Journal of Basic and Applied Sciences, vol. 5, no. 12, pp. 1351-1363, 2011.

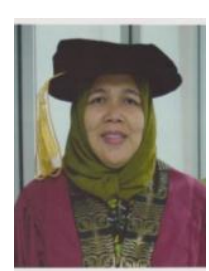

Sarminah Samad is a lecturer in Arshad Ayub Graduate Business School, University Teknologi MARA, UiTM, Malaysia. Her areas of specialization are on human capital mgt \& development, business mgt, corporate strategy, strategic management and organizational studies. She is involved in research related to human capital management, leadership, organizational behavior and studies (job satisfaction, commitment, turnover, employee retention, psychological contract, performance etc.), supply chain management, quality management, organizational performance and business and organizational strategy and excellence (Blue Ocean Strategy, EFQM etc.). She is an active speaker as well in the above related topics. She has published papers in several international refereed journals indexed in ISI, Scopus etc. She has always been invited to serve on the editorial boards, journal reviewers and program committees of several international journals and conferences. She has also been a reviewer to more than 10 international refereed journals and currently she is the chief editorial board of IKAZ International Journal of Philanthropy, UiTM and member of IACSIT. She was a technical committee of IFTIDO and several international and national conference committees. 